\title{
Comparison of the importance and observance of the patient's bill of rights from the perspectives of patients and personnel of hospitals in Kerman
}

Mahlagha Dehghan ${ }^{1}$, Roghayeh Mehdipour-Rabori ${ }^{1 *}$, Masoud Rayani ${ }^{1}$, Mohammad Ali Zakeri², Mina Mobasher ${ }^{3}$, Maryam Iranmanesh ${ }^{4}$, Narges Rezai ${ }^{4}$

1.Assistant Professor, Nursing Research Center, Kerman University of Medical Sciences, Kerman, Iran. 2.Researcher, Non-Communicable Diseases Research Center, Rafsanjan University of Medical Sciences, Rafsanjan, Iran.

3.Assistant Professor of Medical Ethics, Faculty of Iranian Traditional Medicine, Kerman University of Medical Sciences, Kerman, Iran.

4.Researcher, Nursing Research Center, Kerman University of Medical Sciences, Kerman, Iran.

\section{Abstract}

Patients' rights are among the most important criteria for evaluating the quality of health services. The current study aimed to determine the importance and observance of the patient's bill of rights.

This cross-sectional study was done in Kerman, Iran. The research samples were 217 patients and 204 personnel. The data collection tool was a researcher-made questionnaire in the scope of the patient's bill of rights, and data were analyzed by SPSS 15.

The results showed a significant difference between patients and the personnel on the subject of the patient's bill of rights and most of its dimensions $(P<0.01)$. However, no significant difference was found between their views on the observance of the patient's bill of rights and its dimensions. Also, 35.9\% of patients as well as $25 \%$ of personnel considered the observance of patients' rights unfavorable.

The participants were aware of the importance of the patient's bill of rights. It is necessary, however, to codify and approve the laws related to the rights of patients.

Keywords: Patients' rights; Clinical ethics; Patients' bill of rights.
${ }^{*}$ Corresponding Author

Roghayeh Mehdipour-Rabori

Nursing Research Center, Kerman University of Medical Sciences, Haft Bagh, Alavi Road, Kerman, Iran.

Tel: (+98) 3431325219

Email: $\underline{r \text { mehdipour@kmu.ac.ir }}$

Received: 18 May 2019

Accepted: 6 May 2020

Published: 2 June 2020

Citation to this article:

Dehghan M, Mehdipour-Rabori R, Rayani M, Zakeri MA, Mobasher M, Iranmanesh M, Rezai N. Comparison of the importance and observance of the patient's bill of rights from the perspectives of patients and personnel of hospitals in Kerman. J Med Ethics Hist Med. 2020; 13: 5. 


\section{Introduction}

In recent years, societies have focused on individual and social ethics and rights, as well as the dignity of human beings. As a result, the concepts of patients' rights and their support have been considered (1). The Universal Declaration of Human Rights in 1948 has defined patients' rights based on the concept of equality of all human beings (2). Patients' rights refer to specific legal privileges related to patients' physical, psychological, spiritual and social needs that the healthcare system and the medical team observe them. $(3,4)$. On account of the increasing ethical challenges in medical care, policies have been devised to pay more attention to human rights, especially for patients as vulnerable individuals with significant needs (5). Healthcare providers must respect the patient more than ever (6), and in most countries throughout the world, they are required to observe some patients' rights (7). Therefore, the role of professional healthcare is to protect people who cannot defend themselves. The patient's bill of rights (PBR) is a guide to choose and ensure the best future decisions for patients' benefits, and can be the starting point for full attention to patients' rights and a correct definition of the relationship between healthcare clients and providers (8). According to the laws of the American Medical Association, physicians must protect patients and promote their basic rights (9). The patient's bill of rights has been addressed in A lot of countries, so hospitals and healthcare facilities must observe it (10). In Iran, the Health Deputy at the Ministry of Health and Medical
Education compiled the Patient's Bill of Rights in 2002 and sent it to the subordinate organizations $(11,12)$.

The bill of rights includes the following topics: receiving proper services, patient's independence and decision-making rights, respect for the patient, privacy, and access to a complaints system. In some countries, the bill of rights also includes high-quality care, awareness of rights, pain relief, and easy death. (5). Patient's bill of rights creates a sense of security and increases satisfaction, while patient participation in therapeutic affairs reduces the cost of treatment and the length of hospital stay, and also prevents the occurrence of irreversible physical and emotional injuries $(13,14)$. Additionally, observing patients' rights will help improve and control their condition. Dissatisfied patients hardly follow the treatment orders and show fewer signs of recovery, and may leave or change the treatment center with an incomplete course of treatment (15). Therefore, non-compliance with patients' rights can endanger the health, life and safety of patients and weaken the relationship between healthcare personnel and patients, leading to less effective care and services to patients (16). Unfortunately, healthcare providers and clients do not have a proper relationship in many aspects of the patient's bill of rights (17). Studies have shown that in many cases, the patient's bill of rights is not implemented. According to these results $(1,18,19)$, physicians, nurses and hospital managers did not have sufficient knowledge of patients' rights, and these rights were not fully respected in the studied hospitals. In another study, despite 
the excellent knowledge of physicians, the results reported poor observance of the patients' rights (20).

Given the importance of patients' rights and the different degrees of observance of the patient's bill of rights in different societies, the Iranian Ministry of Health has focused on the obsevance of the patient's bill of rights in recent years. Furthermore, few studies have been conducted on the importance and observance of the patient's bill of rights from the viewpoints of patients and healthcare personnel. The current study compared the importance and observance of the patient's bill of rights from the viewpoints of patients and healthcare personnel in Kerman. Therefore, the results can serve as a guide for authorities and professors at universities and improve patients' condition, the quality of health care services, and the professional position of doctors and nurses.

\section{Method}

This cross-sectional study was conducted in Kerman hospitals in 2018-2019. There are 4 governmental hospitals, 3 semigovernmental hospitals, and 2 private hospitals in Kerman, all of which were included in the research setting.

A cluster sampling method was used to collect data. Governmental, semigovernmental, and private hospitals were considered as a cluster, and sampling was then done according to the number of beds in each cluster. A pilot study with a sample size of 20 people (10 personnel and 10 patients) was carried out to estimate the sample size. The mean and standard deviation of observance of the patient's bill of rights from the viewpoints of personnel and patients were $2.84 \pm 0.48$, and $2.66 \pm$ 0.72 , respectively.

The confidence coefficient was $95 \%$, with the confidence range of 1.96 , and type II error was $20 \%$ (0.84). Therefore, the sample size for each group was estimated to be 136, which, according to the cluster sampling method, was multiplied by 1.5 . Finally, the sample size for each group was 204 .

The study population consisted of patients admitted to hospitals in Kerman, aged $\geq 16$, who were mentally and physically capable of answering questions, as well as the healthcare staff (nurses, midwives and doctors). The researchers started cluster sampling after obtaining permission from the Kerman University of Medical Sciences, and explaining their goals to the participants. A self-report questionnaire was used to collect information. In the case of illiterate patients, the researcher interviewed them and completed the questionnaire for them.

A two-part questionnaire was used to collect information. The first part of the questionnaire collected demographic information, including: 1) age, sex, marital status, level of education, occupation and income level for the patients, and 2) age, sex, marital status, level of education, occupation, type of employment and work experience for the staff (nurses, midwives, and doctors). The second part, a researchermade questionnaire, was related to the ethics 
in the area of the patient's bill of rights and was completed by the patients and the staff. Therefore, focusing on the patient's bill of rights, the researchers formulated a questionnaire containing 20 items in 5 areas: "receiving optimal healthcare services" (9 items); "information provision" (4 items); "free decision-making" (2 items); "privacy and confidentiality" ( 2 items); and "access to an effective complaints handling system" (3 items). Each statement of the questionnaire was measured based on a two-point Likert scale. The significance of each phrase was measured using a 5-point Likert scale (very important $=4$, important $=3$, somewhat important $=2$, not important $=1$, and I have no idea $=0$ ). The observance rate of each statement was also measured using a 5-point Likert scale (always observed $=4$, often observed $=3$, sometimes observed $=2$, rarely observed $=1$, and not observed at all $=0$ ). The mean score was used to calculate scores. Therefore, the score range of significance and observance rate of the patient's bill of rights varied from 0 to 4 , with higher scores indicating more important ethics and better observance. Also, in the area of observance of patients' rights, mean scores of $0-1.34,1.35-2.67$ and above 2.67 were rather unfavorable, undesirable, and desirable, respectively. To determine the validity of this questionnaire, 5 experts in the field of medical ethics reviewed it, and their opinions were used to complete and correct the items. Internal consistency was used for reliability. The questionnaires were then distributed to 20 target people (10 patients and ten personnel), and Cronbach's alpha was calculated. The Cronbach's alpha values for the importance and observance of the patient's bill of rights were 0.88 and 0.81 from the staff's point of view, and 0.87 and 0.85 from the patients' point of view.

\section{Data Analysis}

SPSS 15 was used to analyze the data. Descriptive statistics (frequency, percentage, mean, and standard deviation) was used to describe the characteristics of the participants. Since the importance and observance scores of the patient's bill of rights were not within the normal distribution range in either group, nonparametric inferential statistics was used (Mann-Whitney U and Spearman correlation coefficient).

\section{Ethical Considerations}

The permission and a written letter of introduction were obtained from the Research Dean of Kerman University of Medical Sciences and the Ethics Committee of Afzalipour Hospital (IR.KMU.REC.1395.11) during data collection. The researchers fully respected the principles of data confidentiality.

\section{Results}

A total of 217 patients and 204 healthcare personnel participated in this study. The demographic characteristics of patients and healthcare personnel were reported in Tables 1 and 2, respectively. The mean age of the patients was $43.88 \pm 18.5$, and the mean age of the healthcare personnel was $30.1 \pm 6.92$. 
Table 1- Demographic characteristics of patients $(n=217)$

\begin{tabular}{|lcc|}
\hline Variable & Frequency & Valid Percent \\
Healthcare provider centers & & \\
Private hospitals & 41 & 18.9 \\
Semi-governmental & 27 & 12.4 \\
hospitals & 149 & 68.7 \\
Governmental hospitals & & \\
Age (year) & 68 & 33.3 \\
Less than 31 & 34 & 16.7 \\
Between 31 - 40 & 27 & 13.2 \\
Between 41 - 50 & 30 & 14.7 \\
Between 51 - 60 & 45 & 22.1 \\
Over 60 & & \\
Sex & 89 & 41.6 \\
Male & 125 & 58.4 \\
Female & & \\
Marital status & 36 & 16.7 \\
Single & 168 & 77.8 \\
Married & 12 & 5.5 \\
Other & & \\
Education & 28 & 13.6 \\
Illiterate & 46 & 22.3 \\
Reading \& writing literacy & 81 & 39.3 \\
Diploma & 51 & 24.8 \\
College education & & \\
Job & 112 & 11.3 \\
Housewife/unemployed & 20 & \\
Employee & 23 & \\
Self-employed & & \\
Retired & & \\
\hline
\end{tabular}


Table 2- Demographic characteristics of personnel $(n=204)$

\begin{tabular}{|c|c|c|}
\hline Variable & Frequency & Valid percent \\
\hline \multicolumn{3}{|l|}{ Place of service } \\
\hline Private hospitals & 42 & 20.6 \\
\hline Semi-governmental hospitals & 25 & 12.2 \\
\hline Governmental hospitals & 137 & 67.2 \\
\hline \multicolumn{3}{|l|}{ Age (year) } \\
\hline Less than 31 & 103 & 57.2 \\
\hline Between 31 - 40 & 62 & 34.4 \\
\hline Over 40 & 15 & 8.4 \\
\hline \multicolumn{3}{|l|}{ Sex } \\
\hline Male & 31 & 15.9 \\
\hline Female & 164 & 84.1 \\
\hline \multicolumn{3}{|l|}{ Marital status } \\
\hline Single & 70 & 35.4 \\
\hline Married & 124 & 62.6 \\
\hline Other & 4 & 2 \\
\hline \multicolumn{3}{|l|}{ Education } \\
\hline Diploma & 24 & 11.8 \\
\hline Associate degree & 3 & 1.5 \\
\hline BS*. & 153 & 75.4 \\
\hline MS**. & 7 & 3.4 \\
\hline PhD*** & 13 & 6.4 \\
\hline Specialized degree & 3 & 1.5 \\
\hline \multicolumn{3}{|l|}{ Profession } \\
\hline Midwife & 29 & 14.4 \\
\hline Nurse & 157 & 77.7 \\
\hline Doctor & 16 & 7.9 \\
\hline \multicolumn{3}{|l|}{ Type of employment } \\
\hline Permanent & 38 & 20.4 \\
\hline Temporary-to & 29 & 15.6 \\
\hline Contractual & 52 & 28 \\
\hline Human source plan & 67 & 36 \\
\hline \multicolumn{3}{|l|}{ Work experience (year) } \\
\hline Less than/equal to 5 & 90 & 54.9 \\
\hline Between 6 and 10 & 35 & 21.3 \\
\hline Over 10 & 39 & 23.8 \\
\hline Bachelor of Science & cience & *** Philosophy Doctor \\
\hline
\end{tabular}

The table 3 shows the importance and observance rate of the patients' bill of rights from the view point of the study participants. According to table 3 , a significant difference was found between the patients and the personnel in the importance of the patient's bill of rights and most of its dimensions, since patients' rights were more important to the patients. No significant difference was found between the patients and the personnel in the observance of the patient's bill of rights and its dimensions, except in "access to an effective complaints handling system". Also, $3.2 \%(n=7)$ of the patients considered 
observance of patients' rights rather unfavorable, $32.7 \%(\mathrm{n}=71)$ unfavorable, and $64.1 \%(\mathrm{n}=139)$ desirable. One percent $(\mathrm{n}=2)$ of the personnel considered observance of patients' rights very undesirable, 24\% ( $\mathrm{n}=49)$ unfavorable, and $75 \%(\mathrm{n}=153)$ desirable.

Table 3- The importance and observance rate of the patient's bill of rights and its dimensions from the viewpoints of all participants

\begin{tabular}{|c|c|c|c|c|c|c|c|c|}
\hline \multirow[b]{2}{*}{$\begin{array}{l}\text { Patient's Bill } \\
\text { of Rights }\end{array}$} & \multicolumn{5}{|c|}{ Importance Rate } & \multicolumn{3}{|c|}{ Observance Rate } \\
\hline & $\begin{array}{c}\text { Patients } \\
\text { (mean \& } \\
\text { standard } \\
\text { deviation) }\end{array}$ & $\begin{array}{c}\text { Personnel } \\
\text { (mean \& } \\
\text { standard } \\
\text { deviation) }\end{array}$ & $\begin{array}{c}\text { Test } \\
\text { Statistic }\end{array}$ & $P$ & $\begin{array}{l}\text { Patients } \\
\text { (mean \& } \\
\text { standard } \\
\text { deviation) }\end{array}$ & $\begin{array}{l}\text { Personnel } \\
\text { (mean \& } \\
\text { standard } \\
\text { deviation) }\end{array}$ & $\begin{array}{c}\text { Test } \\
\text { Statistic }\end{array}$ & $P$ \\
\hline Total Score & $3.56 \pm 0.44$ & $3.47 \pm 0.42$ & -2.52 & 0.01 & $2.91 \pm 0.74$ & $3.02 \pm 0.57$ & -1.3 & 0.19 \\
\hline $\begin{array}{l}\text { Receiving } \\
\text { Optimal } \\
\text { Healthcare } \\
\text { Services }\end{array}$ & $3.65 \pm 0.42$ & $3.61 \pm 0.37$ & -1.93 & 0.05 & $3.11 \pm 0.72$ & $3.09 \pm 0.59$ & -0.99 & 0.33 \\
\hline $\begin{array}{l}\text { Information } \\
\text { Provision }\end{array}$ & $3.52 \pm 0.61$ & $3.39 \pm 0.57$ & -3.08 & 0.002 & $2.81 \pm 0.98$ & $2.92 \pm 0.75$ & -0.45 & 0.65 \\
\hline $\begin{array}{l}\text { Free Decision- } \\
\text { Making }\end{array}$ & $3.33 \pm 0.84$ & $3.25 \pm 0.81$ & -1.46 & 0.14 & $2.68 \pm 1.21$ & $2.73 \pm 1$ & -0.33 & 0.82 \\
\hline $\begin{array}{l}\text { Privacy \& } \\
\text { Confidentiality }\end{array}$ & $3.65 \pm 0.62$ & $3.39 \pm 0.63$ & -5.58 & $<0.001$ & $3.21 \pm 0.79$ & $3.19 \pm 0.73$ & -0.66 & 0.51 \\
\hline $\begin{array}{l}\text { Access to a } \\
\text { Complaints } \\
\text { Handling } \\
\text { System }\end{array}$ & $3.44 \pm 0.85$ & $3.39 \pm 0.7$ & -2.07 & 0.04 & $2.37 \pm 1.19$ & $3.01 \pm 0.83$ & -5.52 & $<0.001$ \\
\hline
\end{tabular}

The perspectives of study participants about the importance and observance rate of ethical case law of the patients' bill of rights were presented in table 4 and 5. According to table 4 and 5 , in terms of the importance of the patient's bill of rights, the mean score of all items was higher than three from the viewpoints of all participants (minimum score of 0 and maximum score of 4 ). In the area of observance of the patient's bill of rights from the viewpoint of patients, the highest average scores were related to the items "privacy during treatment and confidentiality" (3.11), "respecting patients and being kind to them" (3.07), "skills of the healthcare team" (3.05), and "respecting the patient's beliefs and religious and cultural values" (3.02). Also, in the area of observance of the patient's bill of rights from the patient's point of view, the lowest average scores were related to the items "compensation for medical errors" (2.05), "how to handle patient's complaints" (2.18), and "patient's right to complain" (2.4). From the viewpoints of patients, the mean scores of 16 items were less than 3 , while from the viewpoints of personnel, only eight items were lower than 3 . 
Table 4- The importance and observance rate of ethical case law of the patient's bill of rights in dimension receiving optional healthcare service from the perspectives of patients and health care personnel

\begin{tabular}{|c|c|c|c|c|c|c|c|}
\hline \multirow{2}{*}{\multicolumn{2}{|c|}{$\begin{array}{c}\text { Case Laws of Patient's } \\
\text { Bill of Rights }\end{array}$}} & \multicolumn{3}{|c|}{ Importance Rate } & \multicolumn{3}{|c|}{ Observance Rate } \\
\hline & & Patients & Personnel & $\boldsymbol{P}$ & Patients & Personnel & $P$ \\
\hline \multirow{9}{*}{ 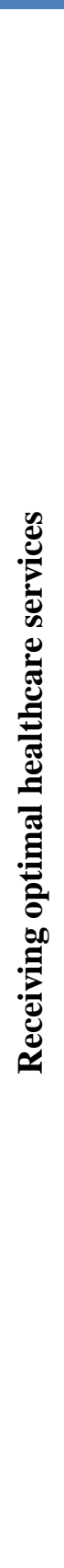 } & $\begin{array}{l}\text { Respecting } \\
\text { patients and being } \\
\text { kind to them }\end{array}$ & $3.81 \pm 0.52$ & $3.81 \pm 0.42$ & 0.40 & $3.07 \pm 1.03$ & $3.32 \pm 0.59$ & 0.14 \\
\hline & $\begin{array}{l}\text { Respecting the } \\
\text { patients' beliefs } \\
\text { and religious and } \\
\text { cultural values }\end{array}$ & $3.36 \pm 1.02$ & $3.62 \pm 0.53$ & 0.11 & $3.02 \pm 0.99$ & $3.32 \pm .64$ & 0.005 \\
\hline & $\begin{array}{l}\text { Being honest with } \\
\text { patients }\end{array}$ & $3.62 \pm 0.75$ & $3.5 \pm 0.75$ & 0.004 & $2.95 \pm 1.06$ & $3.14 \pm .73$ & 0.28 \\
\hline & $\begin{array}{l}\text { Non- } \\
\text { discrimination } \\
\text { among patients for } \\
\text { healthcare services }\end{array}$ & $3.48 \pm 1.0$ & $3.69 \pm 0.7$ & 0.05 & $2.75 \pm 1.22$ & $3.19 \pm 0.84$ & 0.001 \\
\hline & $\begin{array}{l}\text { The skills of the } \\
\text { healthcare team }\end{array}$ & $3.69 \pm 0.76$ & $3.82 \pm 0.4$ & 0.3 & $3.05 \pm 0.93$ & $3.26 \pm 0.77$ & 0.03 \\
\hline & $\begin{array}{l}\text { Paying attention to } \\
\text { health, therapeutic } \\
\text { and emotional } \\
\text { benefits of the } \\
\text { patients when } \\
\text { providing services }\end{array}$ & $3.66 \pm 0.68$ & $3.53 \pm 0.7$ & 0.01 & $2.98 \pm 1.03$ & $3.18 \pm 0.73$ & 0.15 \\
\hline & $\begin{array}{l}\text { Providing well- } \\
\text { being facilities }\end{array}$ & $3.58 \pm 0.79$ & $3.44 \pm 0.66$ & 0.001 & $2.57 \pm 1.28$ & $2.67 \pm 1.01$ & 0.84 \\
\hline & $\begin{array}{l}\text { Respecting } \\
\text { patients' time and } \\
\text { providing fast } \\
\text { services }\end{array}$ & $3.7 \pm 0.67$ & $3.49 \pm 0.64$ & 0.001 & $2.62 \pm 1.28$ & $2.96 \pm 0.96$ & 0.02 \\
\hline & $\begin{array}{l}\text { Paying attention to } \\
\text { the needs of dying } \\
\text { patients and their } \\
\text { families }\end{array}$ & $3.6 \pm 0.78$ & $3.67 \pm 0.64$ & 0.54 & $2.61 \pm 1.25$ & $3.11 \pm 0.81$ & 0.001 \\
\hline
\end{tabular}


Table 5- The importance and observance rate of other dimensions ethical case law of the patient's bill of rights from the perspectives of patients and health care personnel

\begin{tabular}{|c|c|c|c|c|c|c|c|}
\hline \multirow{2}{*}{\multicolumn{2}{|c|}{$\begin{array}{c}\text { Case Laws of Patient's Bill of } \\
\text { Right }\end{array}$}} & \multicolumn{3}{|c|}{ Importance Rate } & \multicolumn{3}{|c|}{ Observance Rate } \\
\hline & & Patients & Personnel & $\boldsymbol{P}$ & Patients & Personnel & $P$ \\
\hline \multirow{4}{*}{ 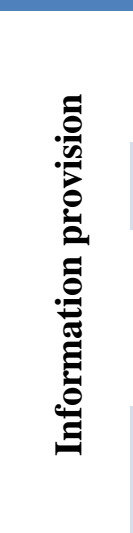 } & $\begin{array}{l}\text { Providing information } \\
\text { about treatment costs } \\
\text { and insurance codes }\end{array}$ & $3.57 \pm 0.76$ & $3.3 \pm 0.76$ & 0.001 & $2.77 \pm 1.18$ & $2.92 \pm 0.86$ & 0.76 \\
\hline & $\begin{array}{l}\text { Introduction of medical } \\
\text { personnel to patients }\end{array}$ & $3.36 \pm 0.89$ & $3.47 \pm 0.7$ & 0.42 & $2.63 \pm 1.24$ & $3.15 \pm 0.9$ & 0.001 \\
\hline & $\begin{array}{l}\text { Providing adequate } \\
\text { information about } \\
\text { diagnostic methods and } \\
\text { therapeutic measures }\end{array}$ & $3.55 \pm 0.77$ & $3.53 \pm 0.69$ & 0.38 & $2.71 \pm 1.18$ & $2.96 \pm 0.88$ & 0.10 \\
\hline & $\begin{array}{l}\text { Providing information } \\
\text { about how to access the } \\
\text { doctor }\end{array}$ & $3.52 \pm 0.84$ & $3.41 \pm 0.67$ & 0.00 & $2.47 \pm 1.3$ & $2.96 \pm 0.92$ & 0.001 \\
\hline \multirow{2}{*}{ 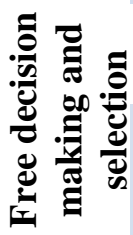 } & $\begin{array}{l}\text { Freedom in selecting } \\
\text { physicians }\end{array}$ & $3.51 \pm 0.84$ & $3.29 \pm 0.91$ & 0.002 & $2.51 \pm 1.36$ & $2.6 \pm 1.18$ & 0.88 \\
\hline & $\begin{array}{l}\text { The right to accept or } \\
\text { reject treatments or } \\
\text { therapeutic offers }\end{array}$ & $3.17 \pm 1.12$ & $3.26 \pm 0.97$ & 0.82 & $2.65 \pm 1.21$ & $2.94 \pm 1.02$ & 0.02 \\
\hline \multirow{2}{*}{ 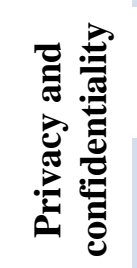 } & $\begin{array}{l}\text { Privacy during } \\
\text { treatment and } \\
\text { confidentiality }\end{array}$ & $3.63 \pm 0.83$ & $3.75 \pm 0.55$ & 0.25 & $3.11 \pm 0.97$ & $3.35 \pm 0.81$ & 0.001 \\
\hline & $\begin{array}{l}\text { The right to having } \\
\text { visitors }\end{array}$ & $3.54 \pm 0.8$ & $3.04 \pm 0.96$ & 0.001 & $2.92 \pm 1.16$ & $3.09 \pm 0.94$ & 0.31 \\
\hline \multirow{3}{*}{ 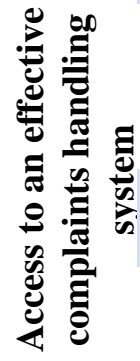 } & $\begin{array}{l}\text { Patients' right to } \\
\text { complain }\end{array}$ & $3.35 \pm 0.98$ & $3.38 \pm 094$ & 0.71 & $2.4 \pm 1.32$ & $3.24 \pm 0.84$ & 0.001 \\
\hline & $\begin{array}{l}\text { How to handle patients' } \\
\text { complaints }\end{array}$ & $3.36 \pm 1.06$ & $3.39 \pm 0.18$ & 0.22 & $2.18 \pm 1.33$ & $3.13 \pm 0.99$ & 0.001 \\
\hline & $\begin{array}{l}\text { Compensation for } \\
\text { medical errors }\end{array}$ & $3.66 \pm 0.84$ & $3.53 \pm 0.75$ & 0.001 & $2.05 \pm 1.5$ & $2.88 \pm 1.07$ & 0.001 \\
\hline
\end{tabular}

\section{Discussion}

The current study compared the importance and observance of the patient's bill of rights from the viewpoints of patients and staff in hospitals of Kerman. The results showed a significant difference between patients and personnel in terms of the importance of the patient's bill of rights and most of its dimensions, as it was found to be more important to patients than personnel. A statistically significant difference was found between patients and personnel in "access to an effective complaints handling system". Also, $35.9 \%$ of the patients and $25 \%$ of the personnel considered the observance of the patients' rights very undesirable or unfavorable.

In the present study, the personnel and patients' mean scores of the importance of patients' rights were above three. The great 
importance of the patient's bill of rights to patients could be due to the fact that based on accreditation, hospitals are required to hold annual courses on patients' rights for personnel, and they have to complete them (21). Also, a study conducted in Izmir on physicians' awareness of the patients' rights showed that $40 \%$ of the physicians were not aware of the patients' rights guidelines, and $63 \%$ of the participants did not even read them (3). According to Rashtabadi's study, nurses' attitudes toward patients' rights will have a positive effect on their performance (22). In the present study, patients' rights were more important to patients than personnel, and since they are the healthcare recipients, the personnel must observe their rights.

The present study showed that from nurses' and patients' viewpoints, the most important aspect of the patient's bill of rights is receiving optimal healthcare services. This has also been demonstrated in a study by Bazmi et al. (23). Doctors and nurses in hospitals are expected to provide healthcare services for patients; therefore, favorable healthcare services are the most important for patients (24).

In this study, the total score for the observance rate of the patient's bill of rights was not good from the viewpoints of the patients and the staff. Various studies have been carried out in Iran, indicating undesirable observance rates of the patient's bill of rights $(25,26)$. Studies have shown that $55.56 \%$ of the doctors in Saudi Arabia (27), 50\% of the doctors and nurses in Egypt (28), $51 \%$ of the nurses and midwives in Turkey (29), and $31.2 \%$ of healthcare staff in Finland were not aware of the patient's bill of rights (30). Studies in different cities of Iran such as Yazd, Shiraz and Hamedan have reported observance of patients' rights to vary between $50.2 \%$ and $53.2 \%$ from the viewpoints of nurses and the healthcare team $(31,32)$. Kazemnezhad and Hesamzadeh reported that the observance of patients' rights from the viewpoints of physicians and nurses was $33.3 \%$ at the poor level and $49.6 \%$ at the average level (18). Basiri Moghadam et al. in Gonabad (2011) showed that although the patients and staff had a good knowledge of the patient's bill of rights, the observance rate was not optimal (33).

A study in Uganda found that at least $36.5 \%$ of the patients encountered a challenge when claiming their rights, while $81.5 \%$ did not know anything about the patient's bill of rights (34). Also, $92.8 \%$ of patients in Sudan (35), and $75 \%$ of patients and their companions in Egypt had no information about the patient's bill of rights (29). In a study by Nekoei Moghaddam et al., despite the desirable knowledge of patients and nurses $(81.5 \%)$, the rate of observance of the patient's bill of rights was not favorable (66.92\%) (25). In Babamahmoodi et al. study in Mazandaran, the lowest observance rate of the patient's bill of rights from patients' viewpoints was 14.59 (36).

Although the observance of the patient's bill of rights has been highlighted in Iranian hospitals, the performance of healthcare personnel must be changed, and health managers must emphasize the observance of the patient's bill of rights in hospitals.

From the viewpoints of staff and patients, the highest score in the observance of the patient's bill of rights was related to privacy and confidentiality. Humayun et al. showed that privacy and confidentiality were rarely 
observed in hospitals, and staff needed more training in observing ethics and patient privacy (37). The lowest score in the observance of the patient's bill of rights was related to free decision-making. According to this study, patients cannot freely choose their physicians, and the patient's right to either accept or reject proposed treatments was not scored favorably. Sultan Ahmadi et al. evaluated the rights of pregnant women in Kerman and obtained the lowest mean score in the area of decision-making (38). Therefore, appropriate action should be taken to ensure that patients can enjoy this right. Meanwhile, the low number of doctors may be one of the reasons why this has not been the case.

Patients may be free to accept the proposed treatment, but they are unlikely to be aware of this right, and the information needs to be provided for patients. In the present study, a statistically significant difference was found between the viewpoints of patients and personnel on accessing an effective complaints handling system and compensation for medical errors. According to patients, these two areas were often not observed. Studies have shown that access to an effective complaints handling system is important for patients $(39,40)$. Friele and Sluijs showed that although only $7 \%$ of patients requested financial compensation, most patients expected impartial judgments about complaints in hospitals (39).

The current study had some limitations. This article cannot be generalized because of the cultural difference between Iranians and people in other countries, as the expectations of patients and personnel are different in various countries.

\section{Conclusion}

In the present study, the importance of the patient's bill of rights was above moderate for both patients and personnel in Kerman. Also, a statistically significant difference was found between patients and personnel in the observance rate of the patient's bill of rights. The score of the observance of the patient's bill of rights was higher from the personnel's point of view compared to the patients' views, but not satisfactory in general. The current study can be used clinically and help hospital managers and macro managers to take steps and enforce laws to better comply with the patient's bill of rights. The results can also be used to train nurses because they showed that the patient's bill of rights was observed from the personnel's perspective, but not from the patients' viewpoint.

\section{Acknowledgements}

The researchers would like to thank very much professor Ali Akbar Haghdoost, Doctor of Philosophy in Epidemiology and bio-statistics in Kerman university of medical science, who tirelessly efforted for this study. The researchers also express their sincere appreciation to the patients and personnel who had contributed to this study.

\section{Conflict of Interests}

The authors declare that there is no conflict of interests. 


\section{References}

1. Nasiriani K, Farnia F, Nasiriani F. Study of respecting patients' rights from nurses point of view employed in Yazd hospitals. Iran J Forensic Med. 2007; 13(1): 33-7. [in Persian]

2. Välimäki M, Kuosmanen L, Kärkkäinen J, Kjervik DK. Patients' rights to complain in Finnish psychiatric care: an overview. Int J Law Psychiatry. 2009; 32(3): 184-8.

3. Özdemir MH, Ergönen AT, Sönmez E, Can IÖ, Salacin S. The approach taken by the physicians working at educational hospitals in Izmir towards patient rights. Patient Educ Couns. 2006; 61(1): 87-91.

4. Hadian Jazi Z, Dehghan Nayeri N. Barriers in the performance of patient's pights in Iran and appropriate offered solutions review article. Journal of Holistic Nursing and Midwifery. 2014; 24(4): 69-79.

5. Abbasi S, Ferdosi M. Do electronic health records standards help implementing patient bill of rights in hospitals? Acta Inform Med. 2013; 21(1): 20-2.

6. Karro J, Dent AW, Farish S. Patient perceptions of privacy infringements in an emergency department. Emergency Medicine Australasia. 2005; 17(2): 117-23.

7. Joolaee S, Tschudin V, Nikbakht-Nasrabadi A, Parsa-Yekta Z. Factors affecting patients' rights practice: the lived experiences of Iranian nurses and physicians. Int Nurs Rev. 2008; 55(1): 55-61.

8. Little J, Mark S. Pharmacy patient bill of rights: practice advancement from the patient perspective. Hosp Pharm. 2013; 48(5): 351-3.

9. Mpinga EK, Chastonay P. Satisfaction of patients: a right to health indicator? Health Policy. 2011; 100(2-3): 144-50.

10. Lawler M, Banks I, et al. The European cancer patient's bill of rights, update and implementation 2016. ESMO Open. 2016;1(6): e000127.

11. Joolaee S, Hajibabaee F. Patient rights in Iran: a review article. Nurs Ethics. 2012; 19(1): 45-57.

12. Parsapoor A, Bagheri A, Larijani B. Review of revolution of patient's right charter. Iranian Journal of Medical Ethics and History of Medicine. 2010; 3(1 and 2): 39-47. [in Persian]

13. Zaree A, Arab M, Akbari F. Managers' knowledge on patient rights in Tehran hospitals. J Qazvin Univ Med Sci 2007, 11(3): 65-71. [in Persian]

14. Hojjatoleslami S, Ghodsi Z. Respect the rights of patient in terms of hospitalized clients: a cross-sectional survey in Iran, 2010. Procedia- Social and Behavioral Sciences. 2012; 31: 464-7.

15. Vahidi R, Kaffashi S, Narimani M, et al. Correlation between knowledge and satisfaction of patients from patient-physician relationship. Journal of Health Promotion Management. 2013; 2(3): 66-73. [in Persian]

16. Fesharaki M, Toufighi $\mathrm{H}$, Nemat EM. A study of physician's attitudes toward patient's rights at shiraz university of medical science - a comparison of patients. rights in Iran with those stated in bill of patient's rights. Teb va Tazkieh. 2000, 36: 59-63. [in Persian]

17. El-Sobkey SB, Almoajel AM, Al-Muammar MN. Knowledge and attitude of Saudi health professions' students regarding patient's bill of rights. Citation manager Int J Health Policy Manag. 2014; 3(3): 117-22.

18. Mahmood Kazemnezhad S, Hesamzadeh A. Implementation of patients' bills of rights by physicians and nurses from their colleagues' points of view in educational hospitals of Mazandaran university of medical sciences. Journal of Mazandaran University of Medical Sciences. 2013; 22(97): 216-23. [in Persian] 
19. Arab M,Zareei A. Patient rights: knowledge of managers of private hospitals. Payesh. 2009; 8(1): 25-30. [in Persian]

20. Abedi G, Shojaee J, Moosazadeh M, et al. Awareness and observance of patient rights from the perspective of Iranian patients: a systematic review and meta-analysis. Iran $\mathrm{J}$ Med Sci. 2017; 42(3): 227-34.

21. Parsapoor A, Bagheri A, Larijani B. Patient's rights charter in Iran. Acta Medica Iranica. 2014; 52(1): 24-8.

22. Rashtabadi O, Borhani $F$, Abbaszadeh A. Nurse' knowledge of patients' bill of rights, level of observation and determining effective factors on them from their viewpoints in Kerman university hospitals. History of Medicine Journal. 2016; 5(17): 37-62. [in Persian]

23. Bazmi S, Kiani M, Hashemi Nazari SS, Kakavand M, Mahmoodzade R. Assessment of patients' awareness of their rights in teaching hospitals in Iran. Med Sci Law. 2016; 56(3): 178-83.

24. Weller JM, Barrow M, Gasquoine S. Inter professional collaboration among junior doctors and nurses in the hospital setting. Med Educ. 2011; 45(5): 478-87.

25. Nekoei Moghaddam M, Amiresmaeili M, Ghorbaninia R, Sharifi T, Tabatabaie S. Awareness of Patients' rights charter and respecting it from the perspective of patients and nurses: a study of limited surgical centers in Kerman city, 2013. Bioethics Journal. 2014; 4(11): 31-56. [in Persian]

26. Ghaljeh M, Khanjani N, Sajadi M, Latifi M, Dastoorpoor M. Awareness from patient right patent and its observance from patients' viewpoint. Journal of North Khorasan University of Medical Sciences. 2015; 7(3): 657-68. [in Persian]

27. Al-Muammar SA, Gari DMK. Doctors' knowledge of patients' rights at King Fahd Hospital of the University. J Family Community Med. 2017; 24(2): 106-110

28. Abou Zeina HA, Nouman AA, Zayed MA, Hifnawy T, El Shabrawy EM, Tahlawy E. Patients' rights: a hospital survey in South Egypt. Journal of empirical research on human research ethics. J Empir Res Hum Res Ethics. 2013; 8(3): 46-52.

29. Hakan Ozdemir M, Ozgür Can I, Ergönen AT, Hilal A, Onder M, Meral D. Midwives and nurses awareness of patients' rights. Midwifery. 2009; 25(6): 756-65.

30. Iltanen S, Leino-Kilpi H, Puukka P, Suhonen R. Knowledge about patients' rights among professionals in public health care in Finland. Scand J Caring Sci. 2012; 26(3): 436-48.

31. Zandiyeh M, Pakro Payravandi A, Imani B, Ahmadi S, Roshanaei G. Quality of compliance of patient's rights in operating rooms of Hamadan's educational hospitals in 2012. Pajouhan Scientific Journal. 2015;13(2): 21-31. [in Persian]

32. Gholami M, Khojastefar M, Moravej H, Kavosi Z. Evaluation of patients' expectations and observation of their rights in the emergency department of Nemazee Hospital during 2015. Iranian Journal of Medical Ethics and History of Medicine. 2016; 9(1): 50-62. [in Persian]

33. Basiri Moghadam K, Basiri Moghadam M, Moslem A, Ajam Zibad H, Jamal F. Health providers and patients' awarness on patient bill of rights and its observing rate in 22 Bahman Hospital. Horizon of Medical Sciences. 2011; 17(1): 45-54. [in Persian]

34. Kagoya HR, Kibuule D, Mitonga-Kabwebwe H, Ekirapa-Kiracho E, Ssempebwa JC. Awareness of, responsiveness to and practice of patients' rights at Uganda's national referral hospital. Afr J Prim Health Care Fam Med. 2013; 5(1). pii: \#491.

35. Younis AA, Hassan AH, Dmyatti EM, Elmubarak MA, Alterife RA, Salim RE, et al. Awareness and practice of patients' rights among hospitalized patients at Wad-Medani Teaching Hospital, East Mediterr Health J. 2017; 23(2): 80-6. 
36. Babamahmoodi F, Meftahi M, Khademloo M, Hesamzadeh A. Observation of patient's right charter in Mazandaran teaching hospitals: patients view. Iranian Journal of Medical Ethics and History of Medicine. 2011; 4(4): 37-44. [in Persian]

37. Humayun A, Fatima N, Naqqash S, et al. Patients' perception and actual practice of informed consent, privacy and confidentiality in general medical outpatient departments of two tertiary care hospitals of Lahore. BMC Medical Ethics. 2008; 9: 14.

38. Soltan Ahmadi Z, Borhani F, Abbaszadeh A, Kohan M. The assessment of the rights of pregnant women attending health centers in Kerman in 2011. Medical Law Journal. 2013; 7(26): 93-110. [in Persian]

39. Friele RD, Sluijs EM. Patient expectations of fair complaint handling in hospitals: empirical data. BMC health services research. 2006;6(1):106.

40. Reader TW, Gillespie A, Roberts J. Patient complaints in healthcare systems: a systematic review and coding taxonomy. BMJ Qual Saf. 2014; 23(8): 678-89. 